\title{
AIRCRAFT TESTING IN TERMS OF METHODOLOGY, SAFETY AND DEVELOPMENT OF AIRCRAFT
}

\author{
Branko B. Bilbija
}

Retired general, Belgrade, Republic of Serbia e-mail: bilbijab@gmail.com,

ORCID iD: i http://orcid.org/0000-0001-5800-0482

DOI: $10.5937 /$ vojtehg65-12681

FIELD: Aerospace, Air Force, Test Ammunition Research Aircraft ARTICLE TYPE: Original Scientific Paper ARTICLE LANGUAGE: English

Abstract:

Aerospace as a whole, primarily aviation and planes, for a short time after 1903, greatly advance the frontiers of human activity. Initially, unsafe "flying device" the plane, has become a factor in "loose" resolving wars and one of the reliable means of transport and communication between people around the world. Quick technical and technological development required a special approach. Mass production and use of aircraft, brought in light the need for standardization in the production, testing and lead into operational use of combat aircraft, as well as in commercial use for the purposes of air traffic. Testing the aircraft, is now more disciplinary research activity of a large number of experts from various fields, including test pilot who is an irreplaceable member. At that goal the test-measuring equipment (IMO), are specifically designed, and test pilots are trained in specialized schools for the experiment pilots.

Keywords: aircraft testing, experimental research, necessity of testing, air force, aircraft aerodynamics, test-measuring equipment, ultra highspeed cameras, telemetry, theodolites, spin, sound barrier, test pilot.

\section{Introduction}

It has only been 113 years since the man's (Wright brothers) first flight with the aircraft whose specific gravity was greater than the specific gravity of the air, with the help of self-propulsion (engine) and the lift on the wings (airfoil). Curiosity, self-assertion and courage as well as an everlasting humans' desire to move in the third dimension like birds were the reasoning behind it (see Figure 1). 


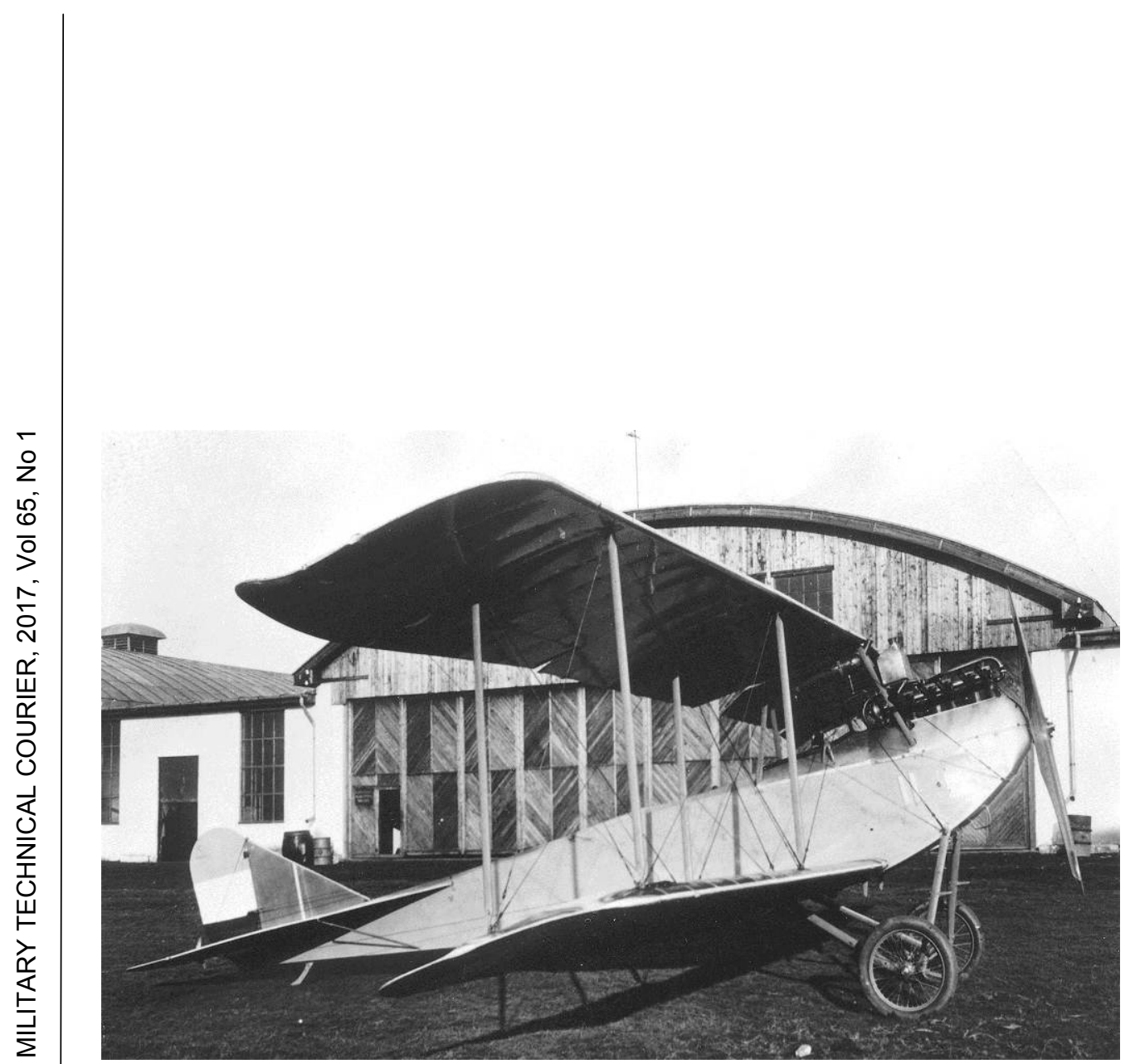

Figure 1 - Ikarus - Rogožarski-small Brandenburg, collection Ognjan Petrović Рисунок 1 - Икарус - Рогожарский малый Бранденбург, коллекция Огнян Петрович Слика 1 - Икарус - „Рогожарски мали Бранденбург” (колекција Огњан Петровић)

It was not before long that military strategists realized the value of the new vehicle and its ability to be used for military purposes. In many countries, including Serbia in 1912 (Janić, Petrović, 2011), this led to the formation of a new service of armed forces (at that time the Army), Air Force (called usually Aviation, Airplane Commands or Units). Names were initially very diverse, and Air Force (AF) or Air Power (AP) were eventually adopted. Very soon in the Great War (World War I), planes were massively used primarily in air combat but also in operations against enemy positions and facilities on land and sea. Combat operations from the air were used on all fronts, especially on the western front, and were performed by all the warring parties. With the development of new technologies, materials, structures, aerodynamics, engines, weapons and equipment, these once unreliable and fragile structures (Janić, Petrović 2011) became a very powerful and reliable means of combat which soon in World War II showed all its value and power; they were often decisive in combat operations. Realizing that the piston engine was a limiting factor for the plane, engineers soon developed a turbojet engine (TM) (at the end of 1930s), which offered completely new solutions and possibilities to the plane. Aerodynamically speaking, after World War II, the plane was in a crisis. It was necessary to resolve the problem of transonic and supersonic speeds. 
The solution was found in suitable airfoil and wing shapes. The door was open.

All structural variations were possible, especially due to the use of new materials (composite materials, new electronic technology, ceramics, etc.). The man soared to unprecedented speed and altitude, and even into space. What was incredible until recently can be seen today in any serious air show or exhibition in the world, leaving the audience amazed, not to mention the use in warfare (Figure 2).

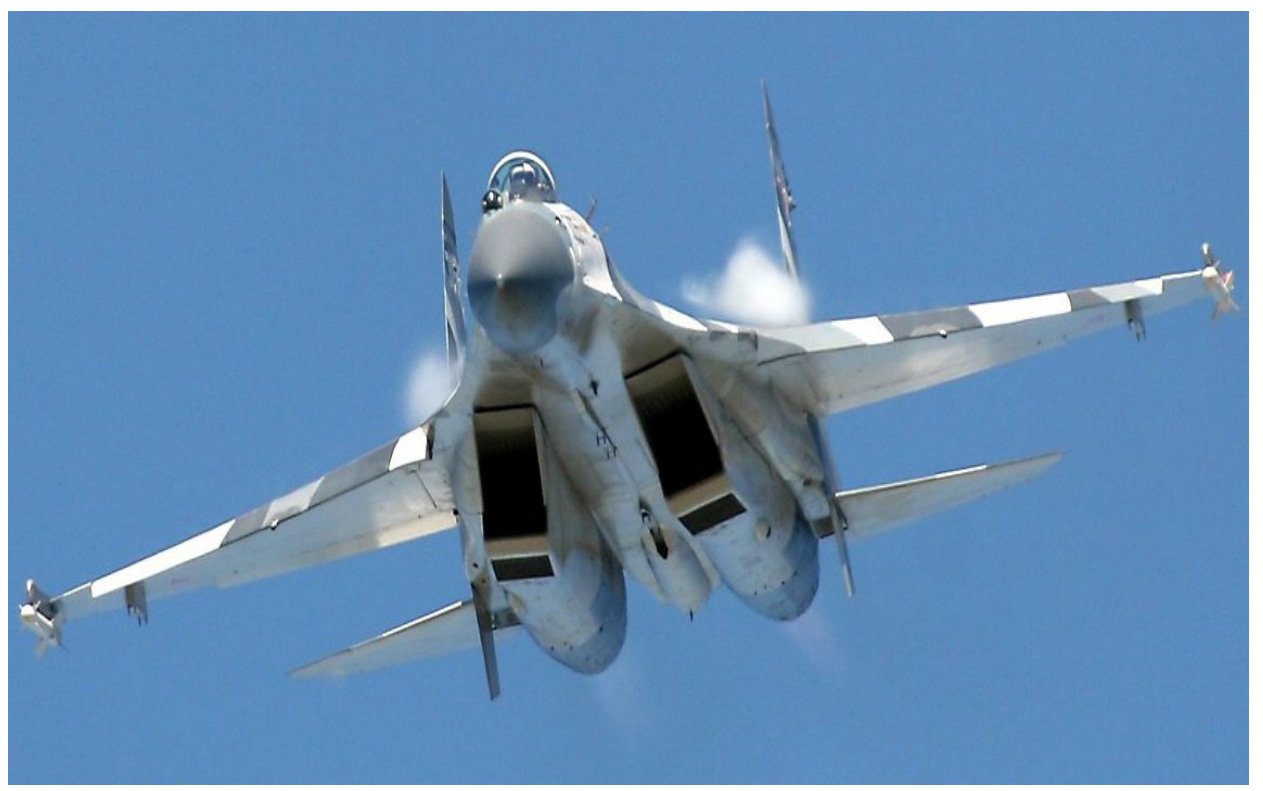

Figure 2 - Aircraft type Sukhoi Su-27

Рисунок 2 - Самолет Сухой, марка Су-27

Слика 2 - Авион типа „сухој” Су-27

Few people wonder how this was accomplished, and whose efforts and knowledge enabled it.

\section{Necessity of tests}

At the very beginning of aviation, airplanes were a product of work of one man or a small team of 2 to 3 people who had the idea to fly. They built airplanes by themselves, checking them constantly. There were many attempts, many failures, unpleasant and even tragic events. However, they continued again, realizing where the mistakes were. They solved problems by feeling and experience, trial and error, until they realized that something 
needed to be measured, analyzed, and appropriate actions taken to resolve problems with the aim of improving the quality, performance and safety of the airplane flight (Bilbija, 2014).

Production of more aircraft, which was a necessity, required the consistency and teamwork of aviation experts from various fields (aerodynamics, engines, weapons, equipment, etc.), where the pilot is one of the key figures in the team. It was possible to be done only by a unified approach and standardization, with measurements in the basis. People realized that only sense and experience can no longer follow the progress and innovations in all fields of science and technology were applied to the airplane. Airplane testing - experimental research is scientific and research work of a large number of aviation experts; it is a multidisciplinary activity which includes forming a testing team, devising testing methods, performance testing on the ground and in the air during the flight, data analysis, drawing conclusions about further activities and the like, with the aim of bringing a tested vehicle to a state of effective and safe use (Bilbija, 1990).

\section{Test-measurement equipment}

Significant development of test and measuring equipment (TME) for testing aircraft began in Europe in the late twenties and early thirties of the last century, mainly in France, Germany and Switzerland. These were the first but significant steps towards the establishment of the base of TME now used for testing of aircraft, engines, weapons and equipment, without which one cannot even imagine quality testing, both for development and verification.

Serbian Air Force, at that time, noticed the value of this approach in the development of aviation and started the education of its members (Capt. Eng. Kosta Sivčev, France, a.Villacoublay), in 1931 (Filipović, 2012) and the acquisition of available TME. Soon, in 1933, the Air Force Test Group (VOG) was formed. It was the forerunner of the TPC (Test Pilot Center) - now the Flight Testing Center - FTC (Dimitrijević, 2003). This was a logical sequence of events in a desire to follow the world trends. So, at the end of the thirties (before World War II), the first lectures about aircraft testing were held by Prof Nenadović at the Faculty of Mechanical Engineering in Belgrade. The first tests and measurements were, practically, "with stick and rope"; soon new monitoring and measuring devices appeared, first for individual parameters of aircraft operation, engine operation and other equipment, and later for monitoring and 
registration of groups or more parameters. The aim was to monitor and register as many elements - parameters during flights as possible to analyze them later after landing and allow the continuation of tests and / or corrections of measurements. After World War II, equipment and devices that were preserved (Arhiv Vazduhoplovnog opitnog centra, 2016), or captured during and after the war were used for testing aircraft, weapons and equipment (Figure 3). Since the existing equipment was already obsolete, new equipment for testing in flight (barographs, registering accelerators, etc.) was purchased in Switzerland in 1949 (Peravia). This equipment, although of modest capability (measuring a maximum of three parameters - data reduced to the time base), allowed successful testing of aircraft and equipment at that time.

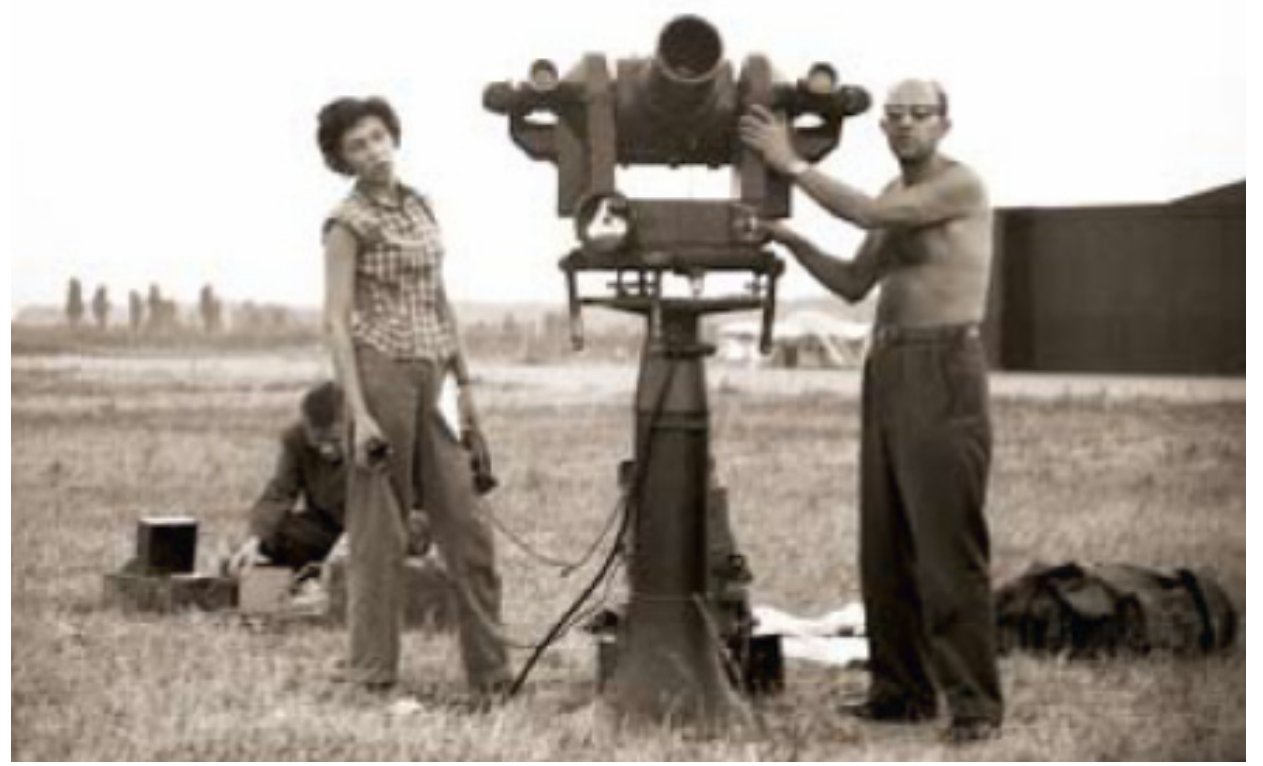

Figure 3 - Pre-war cinetheodolite (Arhiv Vazduhoplovnog opitnog centra, 2016), Рисунок 3 - Довоенный кинотеодолит (Arhiv Vazduhoplovnog opitnog centra, 2016) Слика 3 - Предратни кино теодолит (Arhiv Vazduhoplovnog opitnog centra, 2016)

In line with the development of aircraft, TME also developed so that in the mid-fifties (1956), the TPC acquired modern A20 series photographic recorders of the SFIM French company (Figure 4, 4a, 4b, 4c) (Arhiv Vazduhoplovnog opitnog centra, 2016), (Filipović, 2012).

The purchased photo recorders and cinetheodolites were objective "witnesses" of what really happened in the course of aircraft operation. 


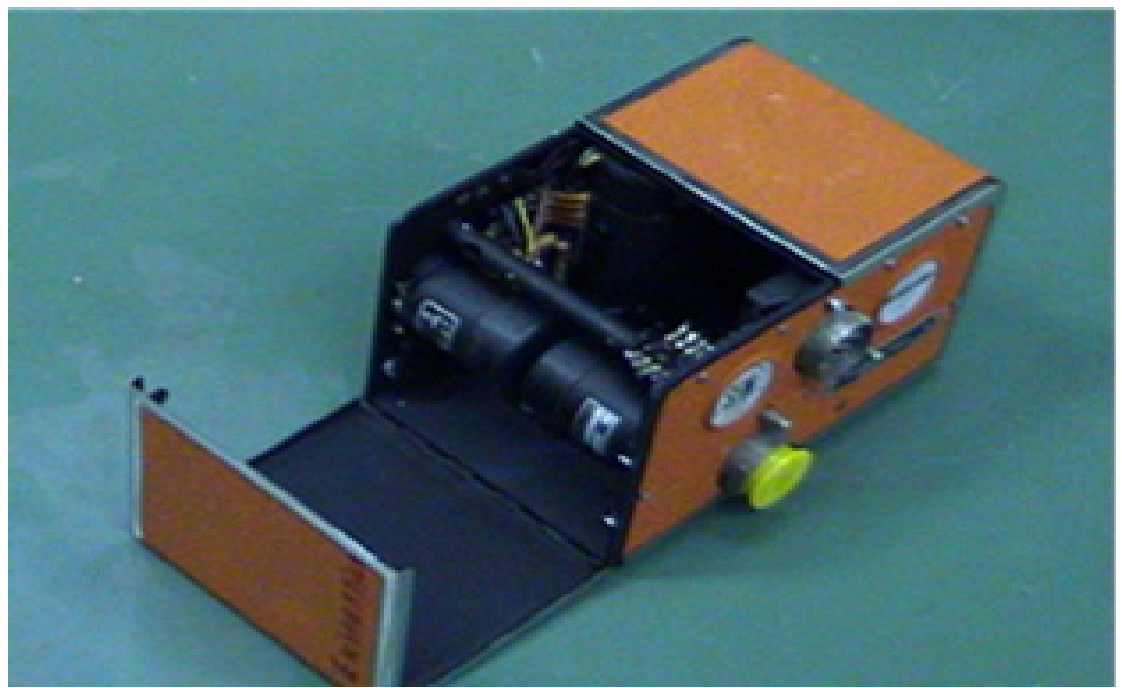

Figure 4 - A20 photo recorder (Arhiv Vazduhoplovnog opitnog centra, 2016) Рисунок 4 - Фоторегистратор A-20 (Arhiv Vazduhoplovnog opitnog centra, 2016) Слика 4 - Фото-регистратор A-20 (Arhiv Vazduhoplovnog opitnog centra, 2016)

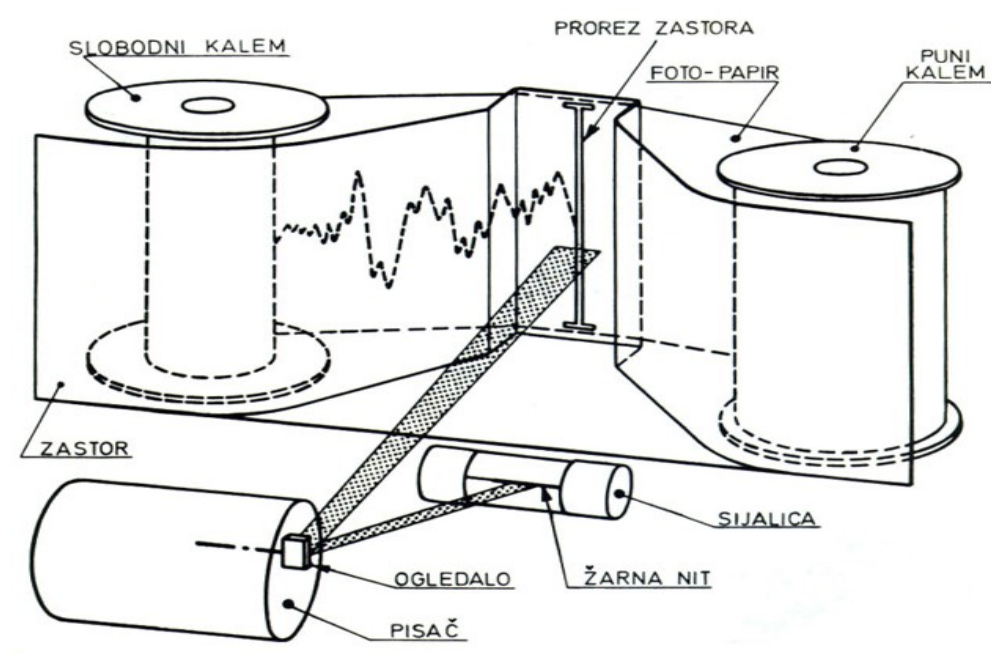

Figure $4 a-$ The principle of A 20 photo recorders

Рисунок 4а - Принцип работы фоторегистратора А 20

Слика $4 a-$ - ринцип рада фото-регистратора А 20 


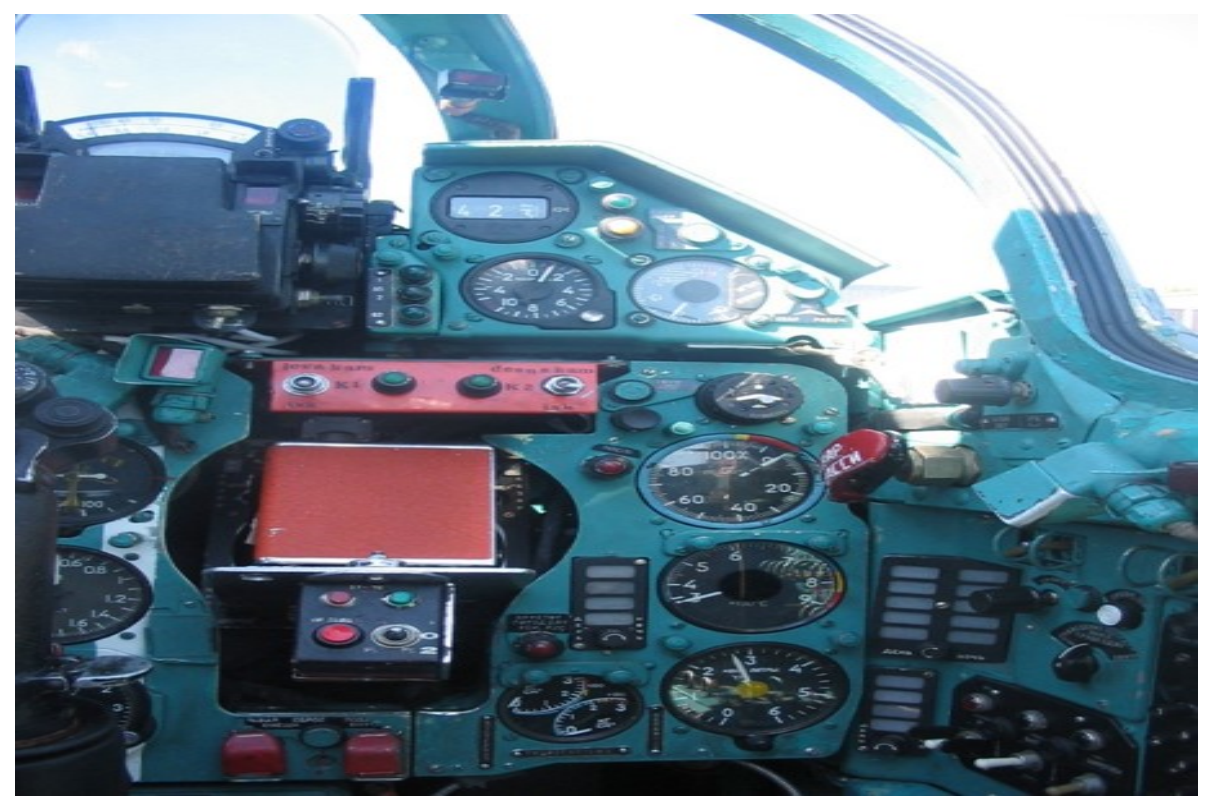

Figure $4 b-$ A20 installed on an MIG 21 (Arhiv Vazduhoplovnog opitnog centra, 2016) Рисунок 46 - А20 установленный в самолете МиГ 21 (Arhiv Vazduhoplovnog opitnog centra, 2016)

Слика 4б - А20 уграђен на авион МИГ 21 (Arhiv Vazduhoplovnog opitnog centra, 2016)

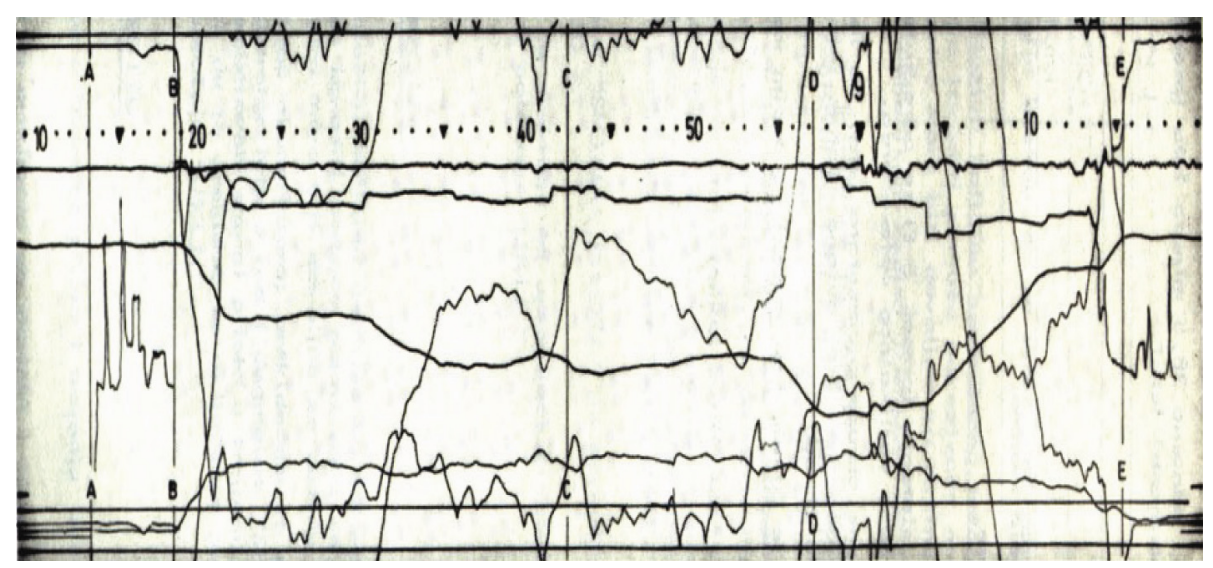

Figure $4 c$ - Record of the monitored parameters on the photo paper of an A20 register during the tests (Arhiv Vazduhoplovnog opitnog centra, 2016)

Рисунок 4c - Запись - отслеживаемых параметров на фотобумаге регистратора A20, сделанная во время испытаний (Arhiv Vazduhoplovnog opitnog centra, 2016) Слика 4 - Запис сниманих - праћених параметара на фото-папиру регистаратора A20 у току испитивања (Arhiv Vazduhoplovnog opitnog centra, 2016) 
The application of test measurement equipment in our country kept pace with global trends of that time. The main goal of using TME was to objectively test and evaluate the quality of the aircraft, arms and equipment so that they could fulfill their purpose.

Regardless of the cooperation with the SFIM Company, the VOC also cooperated with other manufacturers buying their testing equipment - for example the A13 recorder was purchased from SHLUMBERGER. It had a possibility of monitoring and recording up to 24 parameters during the flight (Arhiv Vazduhoplovnog opitnog centra, 2016), which significantly improved the quality and efficiency of tests (see Figure 5).

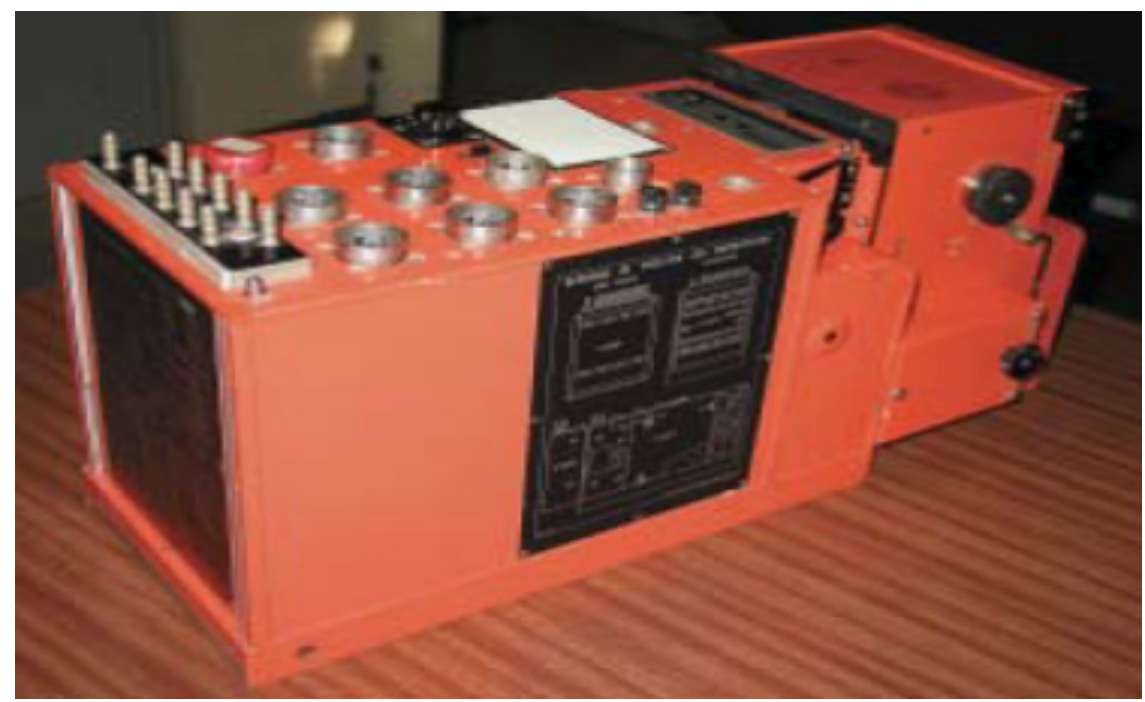

Figure 5 - A13 recorder (Arhiv Vazduhoplovnog opitnog centra, 2016) Рисунок 5 - Регистратор A13 (Arhiv Vazduhoplovnog opitnog centra, 2016) Слика 5 - Регистратор A13 (Arhiv Vazduhoplovnog opitnog centra, 2016)

This is what a so-called "black box" looks like. These recorders are actually BLACK BOXES. They are highly resistant to impact, high temperatures, water, and other types of damage. They are painted in orange on purpose, to make them easier to be identified and found. They got this name in the aviation jargon, because, when an accident or disaster happens, they usually bring black news.

In order to study aviation weapons (firearms, rockets and bombs) as well as the characteristics of aircraft in flight phases, high speed and ultra high speed cameras for continuous recording are used as in other centers for testing aircraft worldwide (Figures 6, 7) (Dimitrijević, 2003), (Filipović, 2012). 


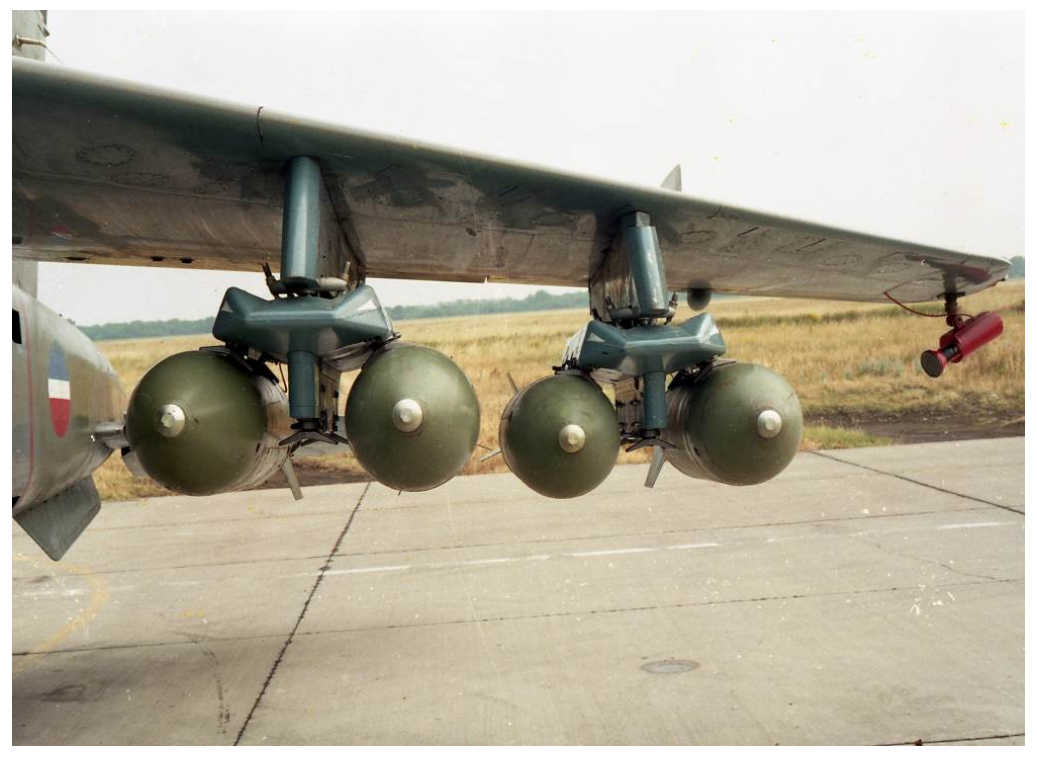

Figure 6 - Ultra high speed cameras to record separation of bombs from bomb-carriers (Arhiv Vazduhoplovnog opitnog centra, 2016)

Рисунок 6 - Сверхскоростная камера для записи сбрасывания бомб с бомбардировщиков (Arhiv Vazduhoplovnog opitnog centra, 2016)

Слика 6 - Ултрабрзе камере за снимање одвајања бомби са бомбо-носача (Arhiv Vazduhoplovnog opitnog centra, 2016)

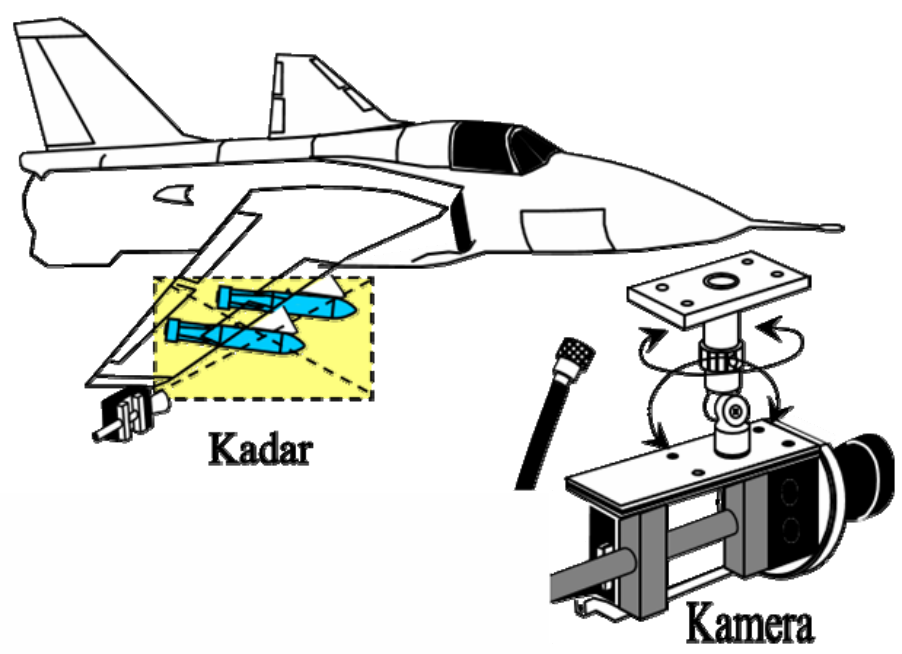

Figure 7 - Scheme of the bomb separation zone recording Рисунок 7 - Схема съемочной зоны при записи сброса бомб Слика 7 - Шема зоне снимања одвајања бомби 
Renowned manufacturers of this equipment also having been used in this country are: AVIA and Sidetel (see Figure 8), (Filipović, 2012), (Arhiv Vazduhoplovnog opitnog centra, 2016).

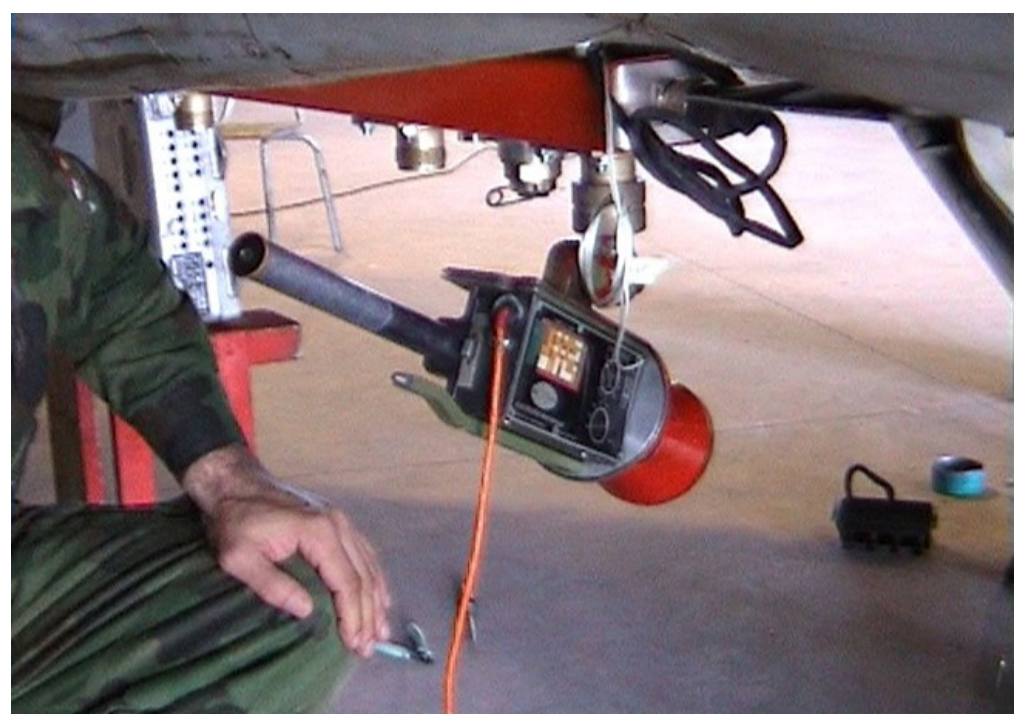

Figure 8 - AVIA camera (Arhiv Vazduhoplovnog opitnog centra, 2016) Рисунок 8 - AVIA камера (Arhiv Vazduhoplovnog opitnog centra, 2016)

Слика 8 - AVIA камера (Arhiv Vazduhoplovnog opitnog centra, 2016)

The digitalization era in the eighties influenced the methodology of testing aircraft, armament and equipment in the VOC, too (Figure 9). It was a huge improvement, because it allowed a simultaneous access to tests data to all participants. In that way, the process of testing and analysis was significantly reduced. 


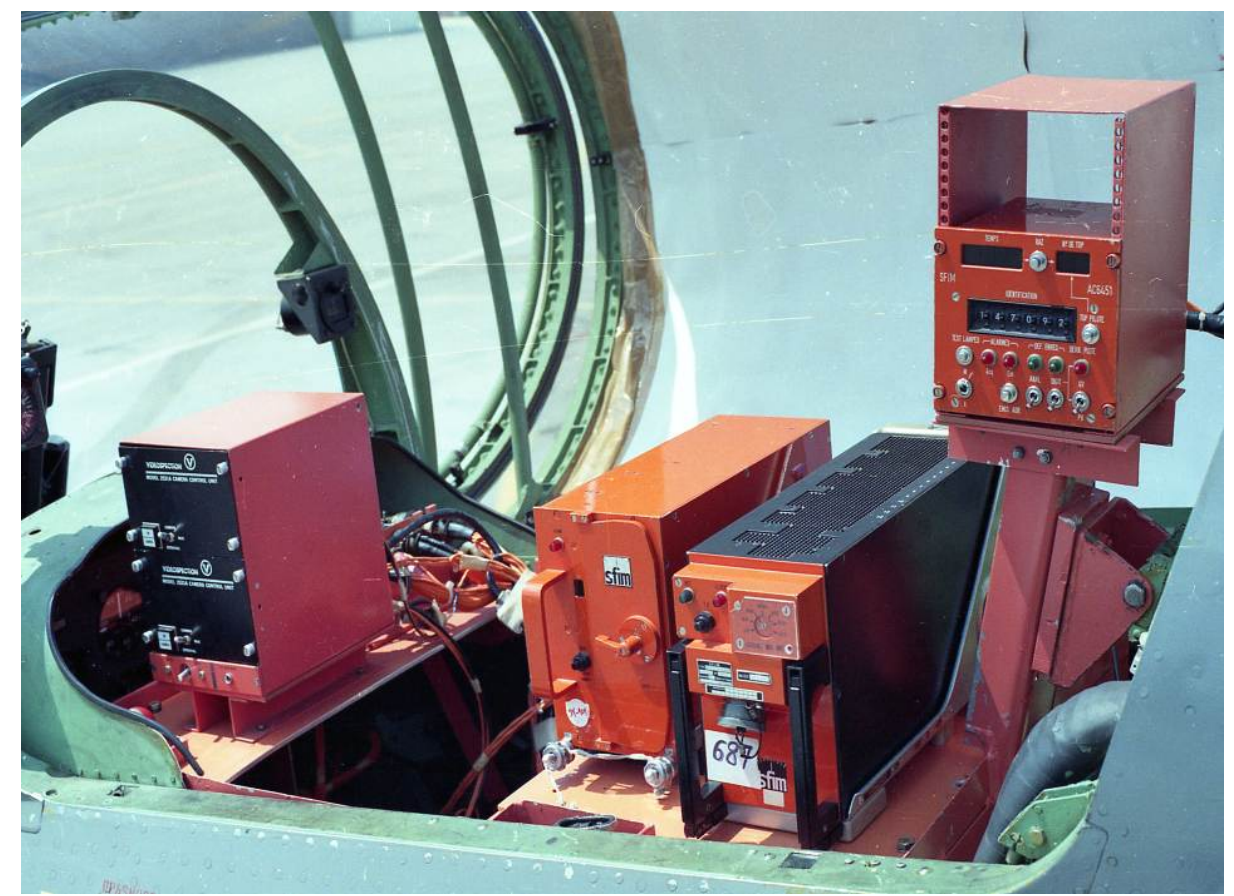

The Air Force Development Plan from the first half of the 1980s dealt with the further development and equipping of the VOC with test measuring equipment (TME). In fact, the development of an NA (new supersonic jet-plane) started. The NA was supposed to be the Yugoslav Air Force variant of the OS, for a longer period, as a fourth-generation multi-purpose aircraft, with the possibility of further improvement (Sredstva za ispitivanje aviona, 2016).

For the purpose of NA quality monitoring and acceptance, the VOC made great efforts in training the entire staff and providing modern equipment for aircraft testing. It was the most modern equipment in the world at that time. 
The optotheodolite system SKYTRACK (Figure 10), of the Swiss company CONTRAVES, was purchased in 1988 and soon put into operation for testing trajectory, flight aircraft, missiles, bombs, parachutes and other means that were tested in the VOC.

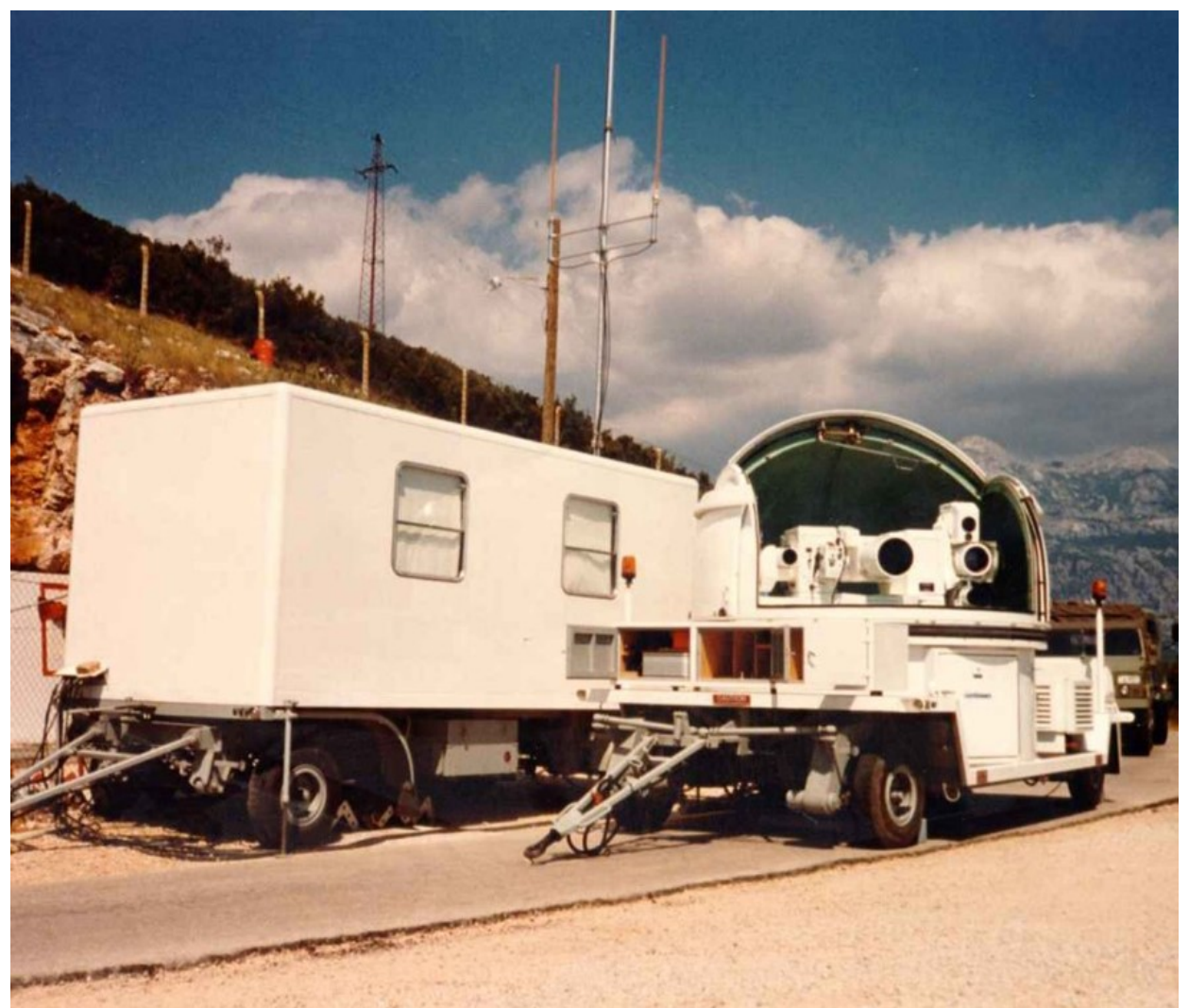

Figure 10 - Optotheodolitesystem SKYTRACK

(Arhiv Vazduhoplovnog opitnog centra, 2016)

Рисунок 10 - Система оптического теодолита "SkyTrack"

(Arhiv Vazduhoplovnog opitnog centra, 2016)

Слика 10 - Оптотеодолитски систем „SKYTRACK”

(Arhiv Vazduhoplovnog opitnog centra, 2016)

The SKYTRACK enabled the capture of the trajectory (Figure 11) of a tested asset at distances from 0.5 to $100 \mathrm{~km}$, depending on the size of the object (combat aircraft and helicopters 15-20 km) being monitored and recorded (Uputstva za teodolite i telemetriju VOC-a,1989). 


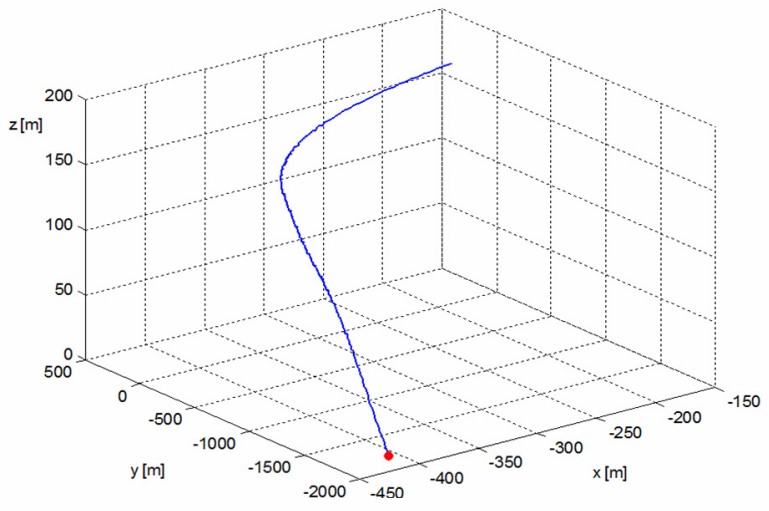

The methods of monitoring and recording are triangulation and laser tracking. The layout of units is given in Figure 12 (Uputstva za teodolite i telemetriju VOC-a, 1989).

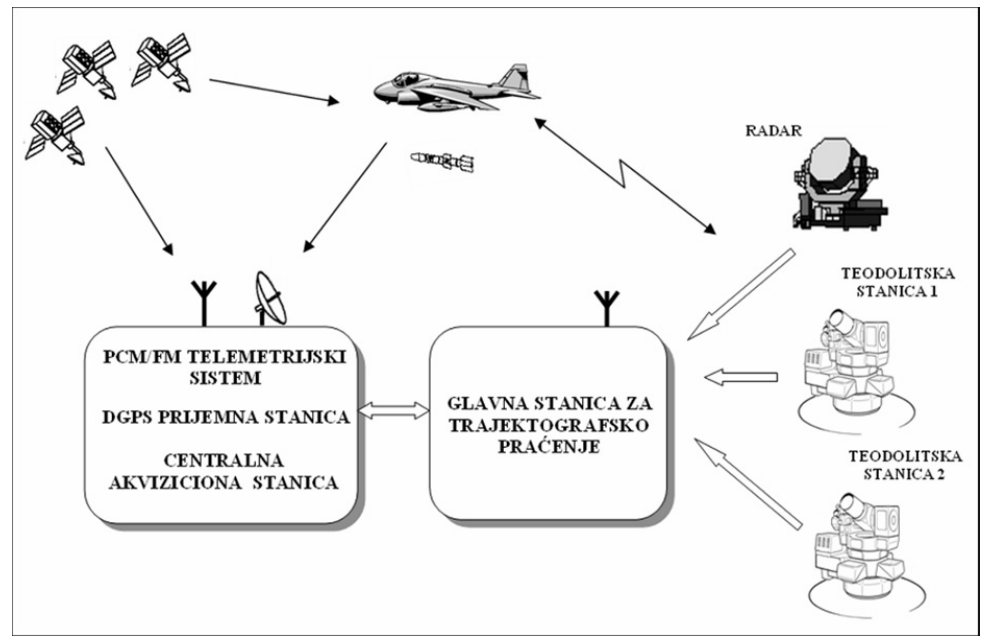

Figure 12 - Scheme of the arrangement of units (telemetry and theodolites) during tests (Arhiv Vazduhoplovnog opitnog centra, 2016)

Рисунок 12 - Блок-схема сбора данных (телеметрия и теодолит) во время испытаний (Arhiv Vazduhoplovnog opitnog centra, 2016)

Слика 12 - Шема распореда јединица (телеметрија и теодолити) у току испитивања (Arhiv Vazduhoplovnog opitnog centra, 2016) 


\section{Telemetry}

The testing of the modern aircraft (named NA in our country) was accompanied by appropriate highly sophisticated equipment for aerodynamic tests and testing of engines, equipment and devices integrated in a plane. For that purpose, in 1989, the telemetry system PCM I FM, of the American firm LORAL (Figures 13, 14), was purchased. The system consists of a so-called ground system - receiving station and a system to be installed on the plane with its sensors and encoders. The system is able to monitor, record and transmit to the receiver station up to 220 parameters - data in real time at distances up to $200 \mathrm{~km}$ (mobile units to $100 \mathrm{~km}$ ), (Uputstva za Teodolite i Telemetriju VOC-a, 1989). The data is immediately registered, monitored and analyzed by the team at the ground-receiver station, so that the team can react immediately and direct a test program in the desired direction. This reduces test time and enables responding to various phenomena in real time during the flight, so that test risks are reduced to a minimum (Sredstva za ispitivanje aviona, 2016).

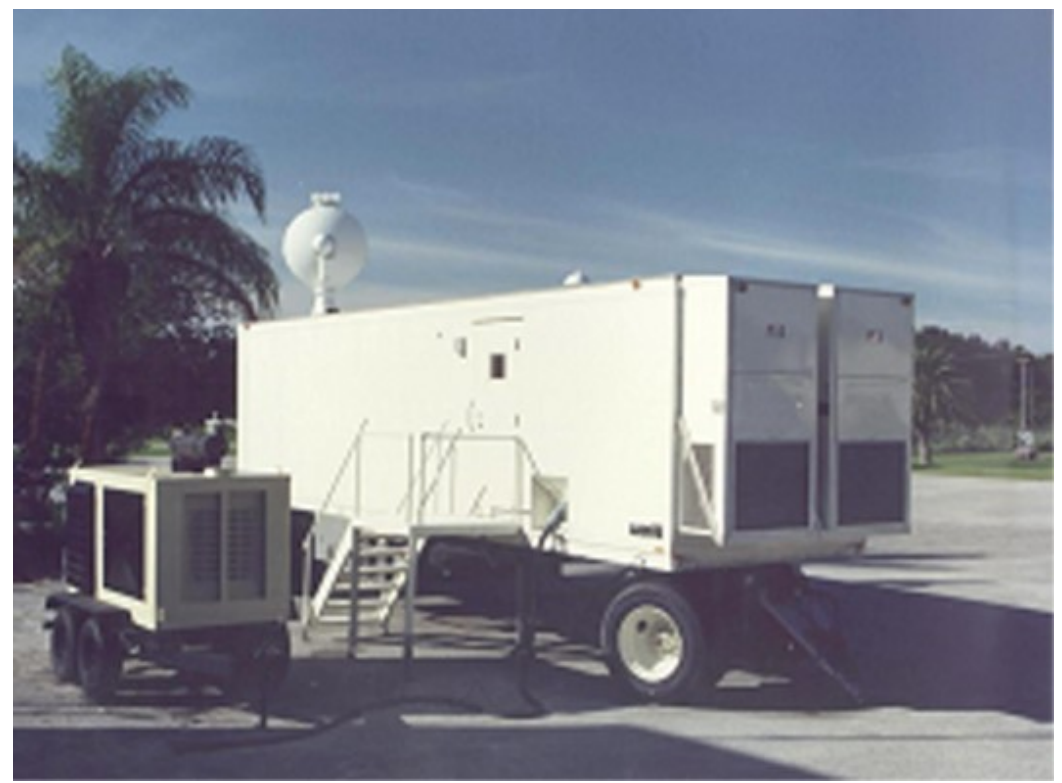

Figure 13 - Telemetry System PCM/FM, US company LORAL - ground receiver mobile station (Arhiv Vazduhoplovnog opitnog centra, 2016)

Рисунок 13 - телеметрическая система PCM / FM, американской компании "LOREAL" - наземная мобильная приемная станция (Arhiv Vazduhoplovnog opitnog centra, 2016)

Слика 13 - Телеметријски систем PCM/FM, америчке фирме „LORAL” - земаљска пријемна покретна станица (Arhiv Vazduhoplovnog opitnog centra, 2016) 


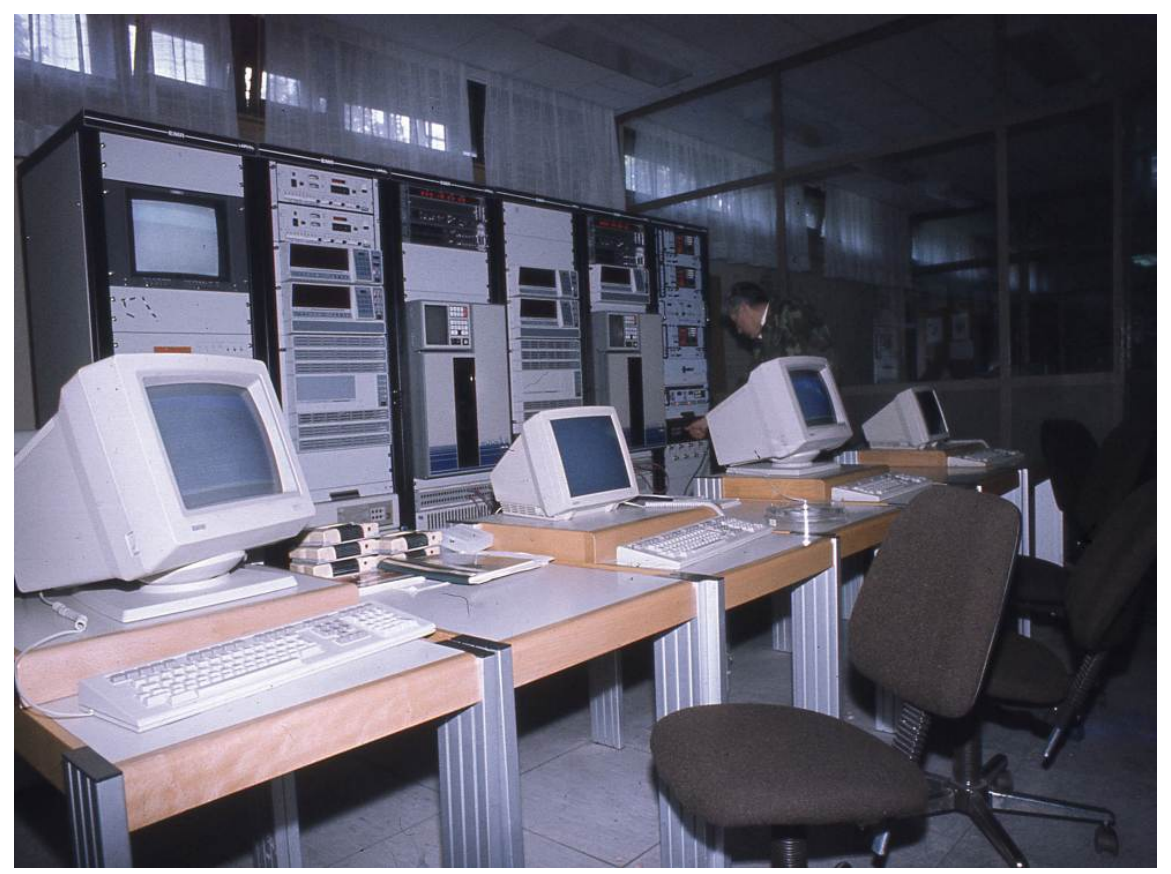

Figure 14 - Telemetry System PCM/FM, US company LOREAL - operator position, (Arhiv Vazduhoplovnog opitnog centra, 2016)

Рисунок 14 - Телеметрическая система PCM/FM, американской компании "LOREAL" - рабочее место оператора (Arhiv Vazduhoplovnog opitnog centra, 2016)

Слика 14 - Телеметријски систем PCM/FM, америчке фирме „LORAL” - позиције оператора (Arhiv Vazduhoplovnog opitnog centra, 2016)

An example of testing efficiency is a spin, evolution in which the inertial forces and moments are dominant in relation to the aerodynamic ones, so performing this evolution can be dangerous (Milošević,1992).

A spin can be generally performed by any plane; it is necessary to find ways to enter it and recover from it while determining its conditions (altitude, speed, entry and recovery). Some fighter jets, from the entry into a spin until complete recovery and stabilization of the flight, lose even several thousand meters.

Therefore, in the spin testing methodology, the "step by step" method is used (a multitude of flights) to reach a complete definition of the behavior of a certain aircraft in a spin (Figure 15, archives of the VOC, photographs, 2016, Belgrade). 

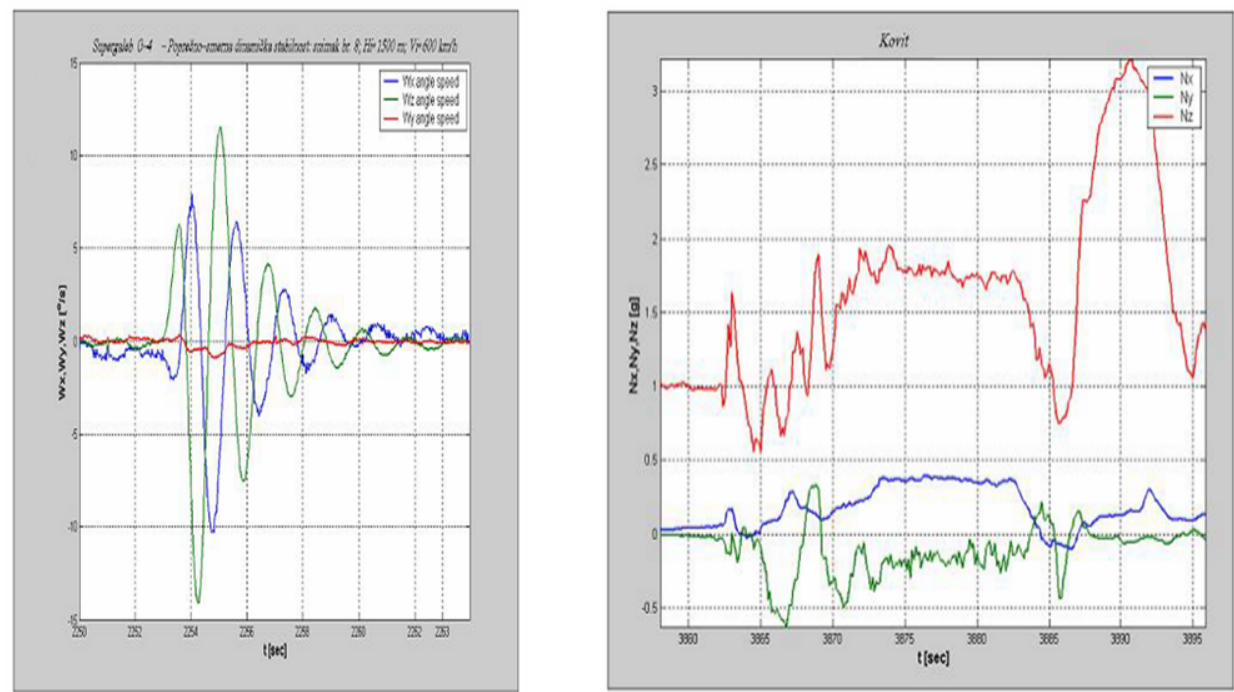

Figure 15 - Graphic display of testing cross directional stability and dynamic spin on the G-4 aircraft

Рисунок 15 - Графическое изображение испытаний поперечной устойчивости и управляемости самолета Г-4

Слика 15 - Графички приказ из испитивања попречно-смерне динамичке стабилности и ковита на авиону Г-4

Telemetry has reduced this kind of tests to a minimum. Instead of recording certain parameters with a photo recorder, their analysis after landing, and repeating attempts, telemetry has allowed a "step by step" method which gives the results only after a few flights, because the control of flight tests is done in real time.

The test pilot and the whole test team are responsible for the security of both the crew and the aircraft, as well as for further consequences of their decision making when determining aircraft performances in a spin, which are further on defined by the aircraft guidelines.

In my pilot experience as a test pilot, I was the first (on my own responsibility since it was forbidden) to perform a spin on an "Eagle" aircraft. I shared this experience with other experiment pilots with whom I flew. Thus, they gained self-confidence and faith in the means they flew on (Arhiv Vazduhoplovnog opitnog centra, 2016). 


\section{Test pilot}

Testing planes is persistent and painstaking teamwork of a large number of specialists - experts, including a test pilot who is an important part of the team (Figure 16). He faces all the problems, successes and failures, and therefore bears a great responsibility (Bilbija, 2014).

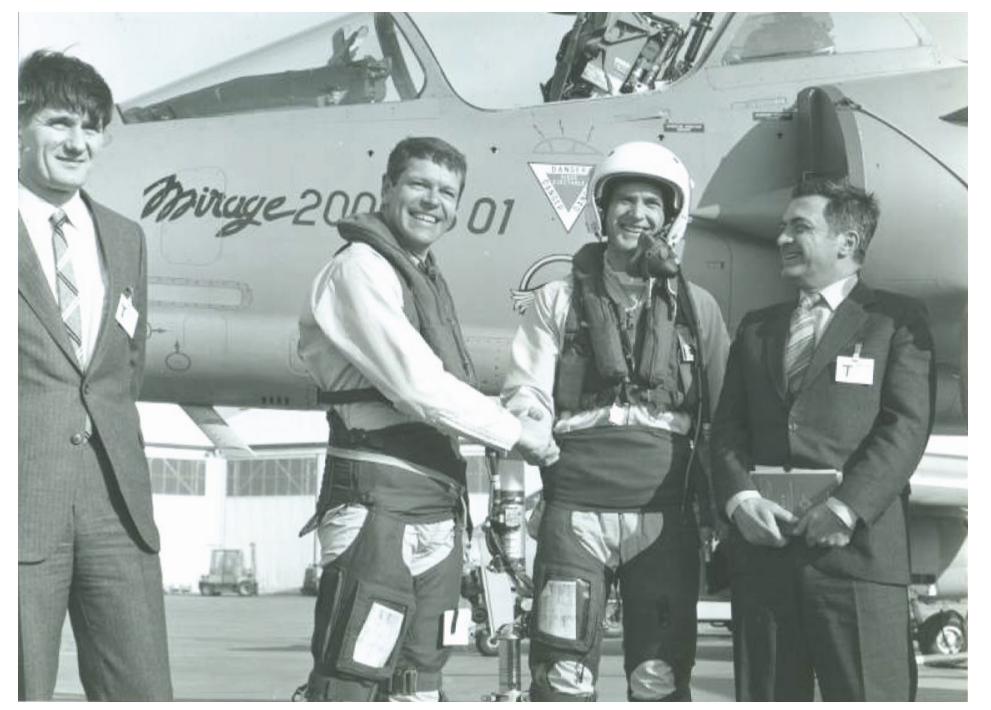

Figure 16 - Test team after a flight (test pilot, Colonel Branko Bilbija, second from the right), French Test Center Istres Marseille, March, 1986.

Рисунок 16 - Команда летчиков-испытателей после полета (Летчик-испытатель, полковник Бранко Билбия, второй справа), Французский авиационный испытательный центр Истр-Марсель, март 1986 года.

Слика 16 - Опитни тим после лета (опитни пилот, пуковник Бранко Билбија, други здесна), Француски опитни центар Истр-Марсеј, март 1986

In the beginning, flight enthusiasts constructed airplanes, flew and carried out tests. It was a romantic era of aviation, where one person or a small team solved all the problems. The development of technologies and their applications in aviation, together with the understanding of the value of aircraft as a means of combat fully differentiated specific areas where experts could engage in aviation. It became clear that only a well-trained pilot could contribute to aircraft development and be a part of the team that solves the problems in the air, and also cooperate with other members engineers and technicians.

The need for a pilot specialist who would be a link with other experts and specialists was realised in the 1930s. The first attempt to form a 
school of test pilots was at the airport Villacoublay, near Paris, in 1935. The aim was to train pilots and flight engineers, in order to standardize testing methodology, unlike the previous practice, where pilots usually had their personal methods and applied them.

The attempt remained only an attempt. However, due to the need to standardise the test criteria and to improve the knowledge in specific areas - aero dynamics, flight mechanics, test techniques and methodologies - for a better understanding of problems and easier communication among experts of different profiles from different fields, the first school for test pilots in the world was established. It was the "Empire Test Pilots School" in Boscombe Down, England, in 1943.

Training of test (Bilbija, 1986), (Bilbija, 1987) pilots and flight engineers fully proved its worth in the further development of aviation and aviation in general. A good example of this is testing the best aircraft climb rate, which is performed in a strictly straight linear flight, with the full power of the engine; it is the product of the aircraft power capabilities.

Also, testing aircraft at defined Mach numbers and high speeds requires appropriate attention and knowledge of testing methodology. In this kind of testing, in contrast to a spin, the airfoil and shape of the wings define in advance the potential of the aircraft, especially at transonic and supersonic speeds. (Milošević, 1981).

Reaching the speed of sound and a value slightly above it with a transonic plane (NJ-22, " Eagle ") (as shown in Figure 17), is performed at a steep angle of descent (30-45 degrees), with the full engine power. The starting height is typically $12,000 \mathrm{~m}$. Thus, depending on the air temperature, (the speed of sound depends only on the air temperature) the speed of sound is reached. The height over $10,000 \mathrm{~m}$ is recommended for this. 


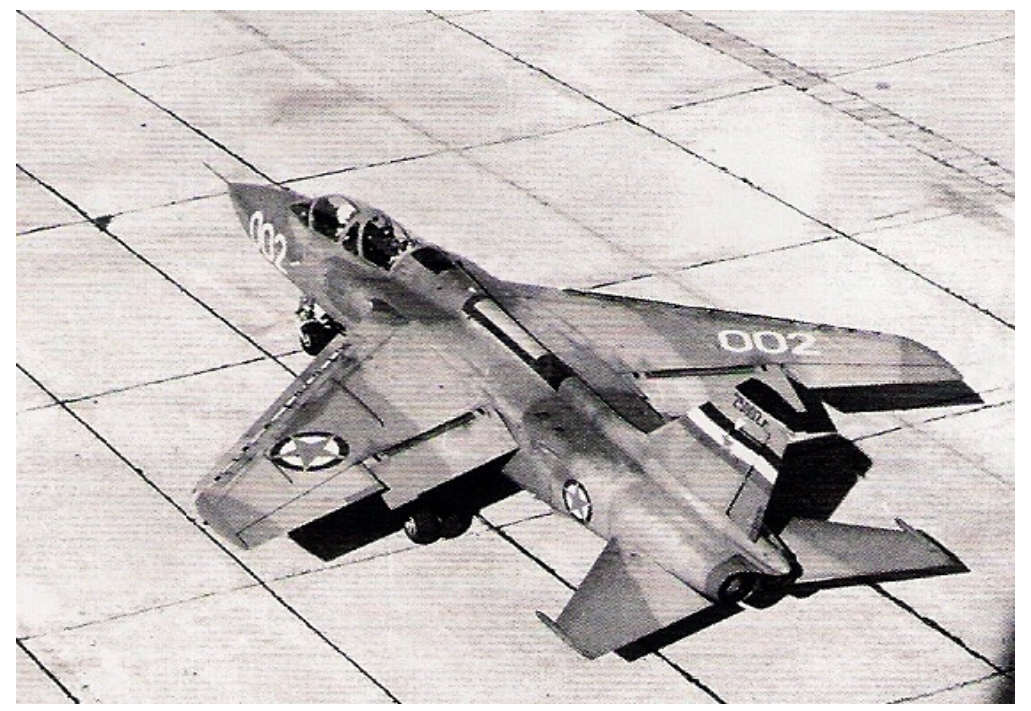

Figure 17 - Orao two-seater in which test pilot Branko Bilbija broke the sound barrier Рисунок 17 - Двухместный «Орел», на котором летчик-испытатель Бранко Билбия преодолел звуковой барьер

Слика 17 - „Орао” двосед којим је опитни пилот Бранко Билбија пробио звучни зид

In peace time, flying at supersonic speeds is done above $10,000 \mathrm{~m}$, due to possible consequences on the ground caused by a shock wave when a plane flies faster than the speed of sound. A shock wave is presented in Figure 18, and its visual effect in Figure 19.
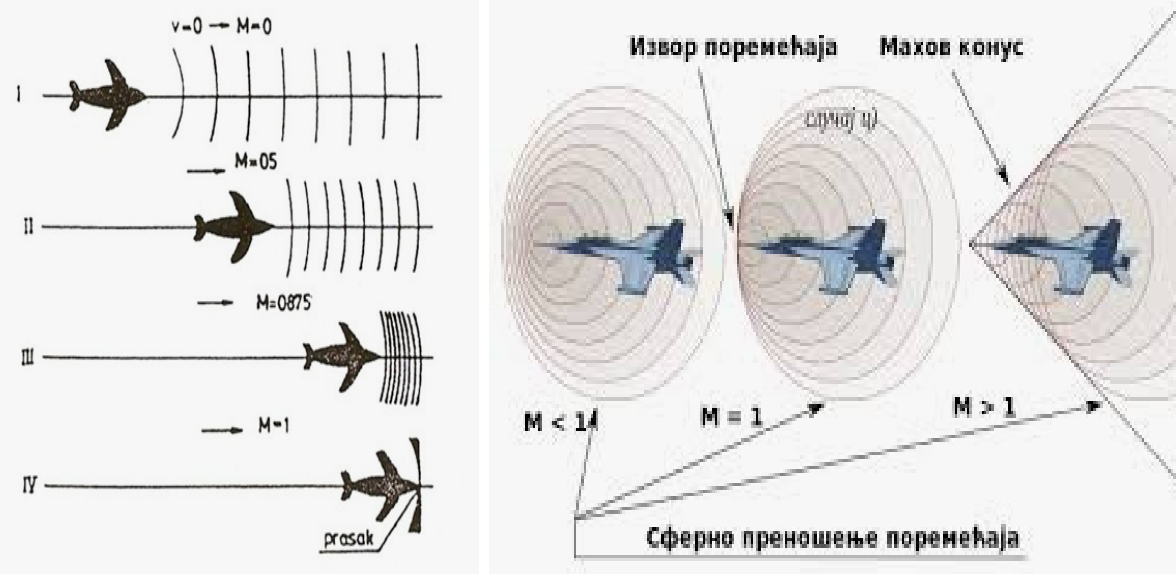

Figure 18 - Shock wave

Рисунок 18 - Изображение ударной волны

Слика 18 - Приказ ударног таласа 
When an aircraft exceeds the speed of sound and enters the zone of supersonic speeds, it causes instant changes in the atmosphere around it. This can be sometimes clearly visible (Figure 19) when the air humidity is high. The change in air pressure in that moment is manifested as a bang on the ground. At that moment, the pilot in the cabin does not feel these changes - everything is silent, and only through instruments (altimeter, variometer and Machmeter), the pilot receives information that his speed is above $M=1$. Speed reduction and transition to the subsonic zone, which is usually done in turn, creates a danger of a sudden increase in the load on the vertical axis due to the change in deflection and the efficiency of the control surfaces, thus affecting the condition of the pilot and the plane. Aircraft using a "fly by wire" control system do not have this problem. Special equipment for supersonic speeds and high altitudes restricts and complicates the work of pilots in each phase of the flight and requires a special training.

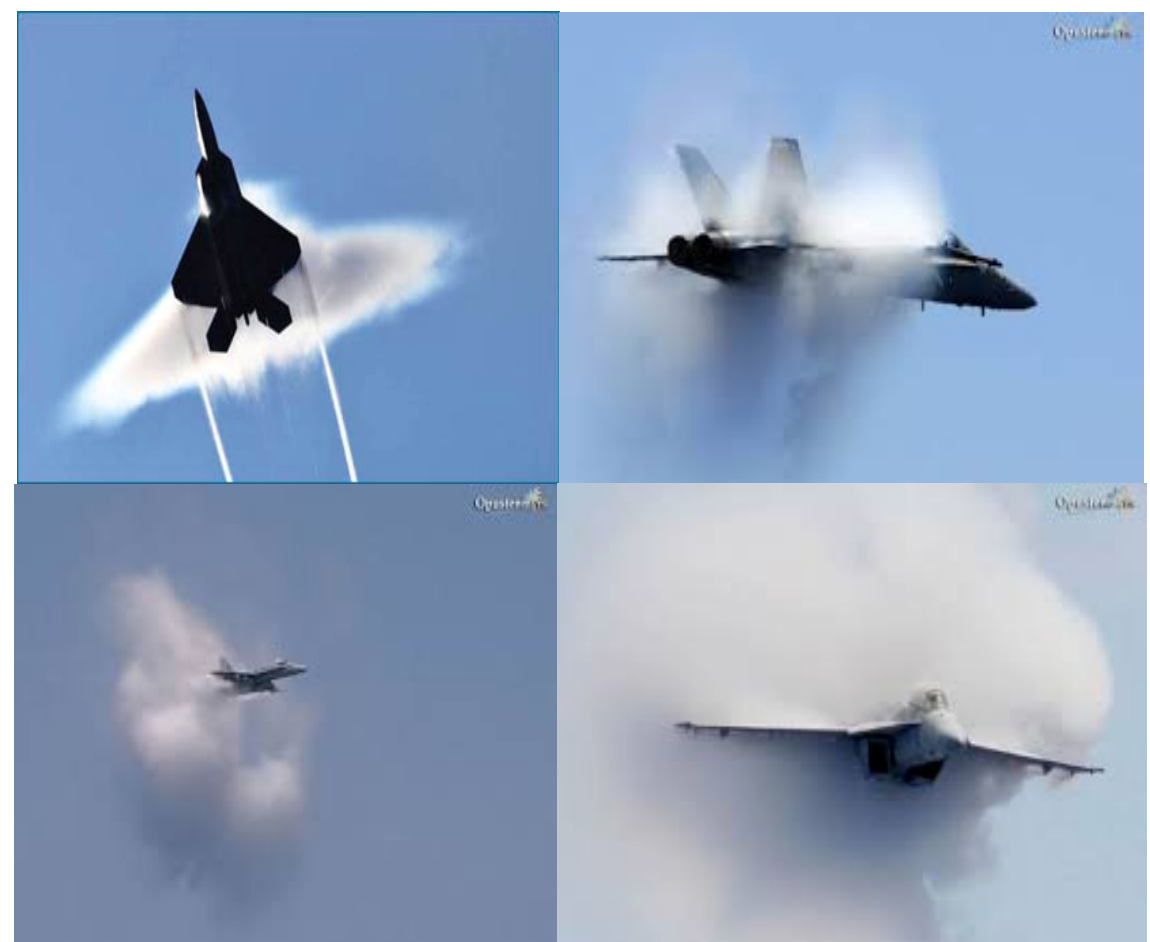

Figure 19 - Display of the visual effects for an aircraft passing Ma = 1 "sound barrier" Рисунок 19 - Изображение визуальных эффректов при прохождении самолета Ма = 1 "стена звука"

Слика 19 - Приказ визуелног ефеката при проласку авиона Мa=1 звучни зид 
The aforementioned has pointed out the need for the specialization in certain stages of testing such as:

- Development testing - these are construction tests performed by pilots and teams of constructors - in this case, the design/construction team was most often the VTI ( MilitaryTechnical Institute), Žarkovo, and tests were also carried out by the test pilots from the Test Pilots Center - VOC (today CLI). These are the tests performed by the designer/constructor to prove whether tactical and technical requirements are met. After successful development testing, a decision is made to move to the next stage.

- Verification testing - in the Test Center, to confirm/verify the test development, performed only by the experts and test pilots from the VOC. It is sometimes possible to include other experts aircraft designers and manufacturers - for specific purposes.

- Tactical tests - for the needs of the tactical use, they are performed in particular Air Force units.

- Tests after the start of the aircraft series production and after performed checks in Overhauling Institutes (RZ), in a tactical unit during regular aircraft maintenance in a unit, done by test pilots trained in the VOC for that type of activity.

The testing process generally finishes in this moment although certain interventions are possible throughout the whole operational life of the aircraft.

\section{Conclusion}

This paper, without going into detailed explanations (otherwise it would have been a lengthy work), intends to show to a layman reader what happened in aviation and what happens next.

One hundred years is a long time, but for aviation it is a very short and dynamic period in which it has developed by leaps and bounds. Designers, engineers, test experts, test pilots and many others are connected, like by Ariadne's thread, by the desire to progress and to achieve new goals. All participants are equally important.

As a final synergetic result, joint work leads to new products. There is no greater satisfaction than success! 


\section{References}

Arhiv Vazduhoplovnog opitnog centra (VOC), 2016. Fotografije. Beograd.

Bilbija, B. 1986. Program obuke opitnih pilota VOC-a. Beograd.

Bilbija, B. 1987. Program obuke opitnih pilota VOC-a. Beograd.

Bilbija, B. 1990. Narodna armija br.2669. Profesija opitni pilot. Beograd.

Bilbija, B. 2014. AM 98, Opitni piloti. Beograd.

Dimitrijević, B. 2003. Vazduhoplovni opitni centar 1933-2003. Beograd.

Filipović, Z. 2012. Ispitno merna oprema. Beograd.

Janić, Č., \& Petrović, O. 2011. Kratka istorija avijacije u Srbiji. Beograd.

Milošević, V. 1981. Program obuke opitnih pilota VOC-a. Beograd.

Milošević, V. 1992. Teorija letenja. Beograd.

Sredstva za ispitivanje aviona 2016. Beograd: Arhiv. Dokumentacija-VOC-a.

Uputstva za teodolite i telemetriju VOC-a 1989. Beograd.

ИСПЫТАНИЯ САМОЛЕТА С ТОЧКИ ЗРЕНИЯ МЕТОДОЛОГИИ, БЕЗОПАСНОСТИ И РАЗВИТИЯ АВИАЦИОННОЙ ТЕХНИКИ

\section{Бранко Б. Билбия}

генерал в отставке, г. Белград, Республика Сербия

ОБЛАСТЬ: авиация, военная авиация, испытания и исследования самолетов

ВИД СТАТЬИ: оригинальная научная статья

ЯЗЫК СТАТЬИ: английский

\section{Резюме:}

Авиация в целом, а в частности развитие конструкций самолетов, в течение короткого времени, начиная с 1903 года, в значительной степени расширили границы человеческой деятельности. Первые «воздухоплавательные снаряды» трудно было назвать безопасными, но вскоре самолеты стали решающим фрактором в войнах и одним из самых надежных средств передвижения и связи между людьми по всему миру. Быстрое техническое и технологическое развитие нуждалось 8 специальной методологии. Массовое производство и применение летательных аппаратов выявили необходимость в стандартизации в области производства, испытаний и их внедрения в военно-боевую эксплуатацию, а также в коммерческую эксплуатацию в целях воздушных перевозок. Таким образом, на сегодняшний день испытания самолетов включают мультидисциплинарные методы, в применении которых 
задействована большая команда специалистов и экспертов, представляющих различные области науки и техники, а главным участником данной команды неминуемо является летчикиспытатель. Для нужд испытательных мероприятий специально разрабатывается контрольно-измерительное оборудование, а сами летчики проходят специальное обучение в центре по подеотовке летчиков-испытателей.

Ключевые слова: испытания самолета, исследования, необходимость в испытаниях, военная авиация, аэродинамика самолета, контрольно-измерительные приборы, сверхскоростные камеры, телеметрия, теодолиты, штопор, звуковой барьер, летчик-испытатель.

\section{ИСПИТИВАЊЕ АВИОНА СА АСПЕКТА МЕТОДОЛОГИЈЕ,} БЕЗБЕДНОСТИ И РАЗВОЈА ЛЕТЕЛИЦЕ

Бранко Б. Билбија

генерал у пензији, Београд, Република Србија

ОБЛАСТ: ваздухопловство, ратно ваздухопловство, опитна истраживања ваздухоплова

ВРСТА ЧЛАНКА: оригинални научни чланак

ЈЕЗИК ЧЛАНКА: енглески

\section{Резиме:}

Ваздухопловство у целини, а пре свега авијација и авиони за кратко време, након 1903. године, увелико су померили границе људске делатности. Од „климавих" и небезбедних летећих справа, авион је постао решавајући фрактор у ратовима и једно од поузданих средстава превоза и комуникације међу људима широм света. Брзи техничко-технолошки развој захтевао је и посебан приступ. Масовна производња и коришћење авиона изнедрили су потребу за стандардизацијом у производњи, испитивању и увођење у оперативну употребу борбених авиона, као и увођење авиона за потребе ваздушног саобраћаја. Испитивање авиона данас је више дициплинарна истраживачка активност великог броја стручњака из различитих области, међу којима је опитни пилот незаобилазни члан. Ради тога се испитно-мерна опрема (ИМО) посебно дизајнира, а опитни пилоти обучавају у специјализованим школама за опитне пилоте.

Кључне речи: испитивање ваздухоплова, опитна истраживања, нужност испитивања, ратно ваздухопловство, аеродинамика авиона, испитно-мерна опрема, ултра брзе камере, телеметрија, теодолити, ковит, звучни зид, опитни пилот. 
Paper received on / Дата получения работы / Датум пријема чланка: 12.11.2016. Manuscript corrections submitted on / Дата получения исправленной версии работы / Датум достављања исправки рукописа: 25.12.2016.

Paper accepted for publishing on / Дата окончательного согласования работы / Датум коначног прихватања чланка за објављивање: 27.12.2016.

(C) 2017 The Author. Published by Vojnotehnički glasnik / Military Technical Courier (www.vtg.mod.gov.rs, втг.мо.упр.срб). This article is an open access article distributed under the terms and conditions of the Creative Commons Attribution license (http://creativecommons.org/licenses/by/3.0/rs/).

() 2017 Автор. Опубликовано в «Военно-технический вестник / Vojnotehnički glasnik / Military Technical Courier» (www.vtg.mod.gov.rs, втг.мо.упр.срб). Данная статья в открытом доступе и распространяется в соответствии с лицензией «Creative Commons» (http://creativecommons.org/licenses/by/3.0/rs/).

(C) 2017 Аутор. Објавио Војнотехнички гласник / Vojnotehnički glasnik / Military Technical Courier (www.vtg.mod.gov.rs, втг.мо.упр.срб). Ово је чланак отвореног приступа и дистрибуира се у складу са Creative Commons licencom (http://creativecommons.org/licenses/by/3.0/rs/). 